\title{
Removal of Tetracycline Hydrochloride (TCH) in Simulated Wastewater by Zero-Valent Iron with Ultrasonic Irradiation (US-ZIV)
}

\author{
Xiang Yi, Jiang Zhu, Yunan Yan, Huiyu Cheng, Wenlai Xu* \\ State Key Laboratory of Geohazard Prevention and Geoenvironment Protection, \\ Chengdu University of Technology, Chengdu 610059, China
}

Received: 11 December 2019

Accepted: 9 June 2020

\begin{abstract}
In this study, ultrasonic radiation zero-valent iron is used to remove tetracycline hydrochloride in aqueous solution. Zero-valent iron was characterized by SEM and XRD. The mechanism of tetracycline hydrochloride removal process by zero-valent iron was proposed. The effects of initial $\mathrm{pH}$, zerovalent iron dosage, ultrasonic power and tetracycline hydrochloride concentration on the removal of tetracycline hydrochloride in the US-ZVI system were studied in detail. The US-ZVI system produces strong reducing agent $\cdot \mathrm{H}$ and new $\mathrm{Fe}^{2+}$, which can rapidly reduce tetracycline hydrochloride. The results show that with the US-ZVI system, a lower initial $\mathrm{pH}$ helps accelerate the removal of tetracycline hydrochloride. In addition, with the US-ZVI system, with the increase of initial zero-valent iron dosage can promote the degradation of tetracycline hydrochloride. However, compared with $\mathrm{pH}$, the zerovalent iron dosage has less effect on the degradation of tetracycline hydrochloride. In addition, the ultrasonic wave improves the degradation of tetracycline hydrochloride by zero-valent iron. The higher the ultrasonic power, the better the removal effect of tetracycline hydrochloride. However, the initial tetracycline hydrochloride dosage has hardly affected on the degradation efficiency of tetracycline hydrochloride. And the improvement of degradation rate is mainly due to the synergy between US and ZVI. Then, the recycling experiments were carried out. Finally, according to liquid chromatographymass spectrometry results, the degradation pathway of tetracycline hydrochloride was proposed.
\end{abstract}

Keywords: tetracycline hydrochloride (TCH), ultrasonic irradiation, zero-valent iron (ZVI), degradation rate, synergistic reaction

\section{Introduction}

Tetracyclines are broad-spectrum antibiotics produced by actinomycetes and are widely used in

*e-mail: xuwenlai2012@cdut.cn

medicine, animal husbandry and aquaculture industry [1-12]. The production and use of tetracyclines are currently ranked second in the world. However, tetracycline is only partially absorbed and metabolized by passive substances during use, and the rest of antibiotics are still discharged out of the body with feces and urine in an active form (matrix or metabolic 
products) $[13,14]$, causing great harm to the ecosystem and human health [15-24]. This may lead to the accumulation of antibiotics in the ecosystem, which can lead to the high levels of antibiotics. Thus causing devastating effect on the microbial community at the bottom of the food chain, and further affecting the stability of the whole food chain. It can also lead to drug resistance in the body, making people take drugs that have no effect on the disease. Therefore, the control and reduction of residual antibiotics in the environment have attracted extensive attention from environmental science and even in the public.

In previous studies, there have been many ways to degrade tetracycline hydrochloride, such as photocatalysis [25-28], ultrasound irradiation [29, 30], multiphase, Fenton method [31] etc. However, these methods have shortcomings such as high cost, low efficiency or long processing time. Therefore, it is necessary to explore an effective treatment process for the medical wastewater containing antibiotics. In recent years, zero-valent iron has got widespread attention [32-35], due to its low cost and high removal efficiency in pollutant. Zero-valent iron has been used to remove toxic and refractory pollutants. $\mathrm{Fe}$ is an active metal with reducibility and the electrode potential is $\mathrm{E}_{0}\left(\mathrm{Fe}^{2+} / \mathrm{Fe}\right)=-0.440 \mathrm{~V}, \mathrm{Fe}^{2+}$ has reducibility and the electrode potential is $\mathrm{E}_{0}\left(\mathrm{Fe}^{3+} / \mathrm{Fe}^{2+}\right)=-0.771 \mathrm{~V}$. Microscopic galvanic cells are formed in the interior of iron chips, $\mathrm{Fe}$ is used as anode, and the electrons are provided by the galvanic corrosion of $\mathrm{Fe}^{0}$ (anode); free radical $\cdot \mathrm{H}$ and newborn $\mathrm{Fe}^{2+}$ are generated under acidic conditions, and microscopic galvanic cells play a leading role in the degradation of organic pollutants in wastewater, as shown in Fig. 1. The method has been used to treat toxic and refractory wastewater, including bromoamine acid wastewater, olive oil wastewater, nitrobenzene wastewater and ABS resin wastewater [36-42]. Therefore, zero-valent iron is an economical and effective method to treat toxic and refractory wastewater.

In order to further increase the treatment efficiency of the ZVI system, the ultrasonic irradiation has been introduced to enhance the ZVI system (i.e., US-ZVI). Furthermore, the zero-valent iron with ultrasonic irradiation (US-ZVI) has been employed to remove the toxic and refractory pollutants such as phenol [43], pentachlorophenol, C.I. [44], nitrobenzene, P-nitrophenol $[45,46]$. According to previous experimental results [44, 47], the observed rate enhancements for the degradation of the pollutants mainly result from the continuous chemical activation, the cleaning of the $\mathrm{Fe}^{0}$ surfaces by acoustic cavitation, and the accelerated mass transport rates of intermediates, products and reactants between the solution phase and the $\mathrm{Fe}^{0}$ surfaces.

In order to study the removal of tetracycline hydrochloride in simulated wastewater by the US-ZVI system, ultrasonic cracking is carried out under certain conditions by adding a certain amount of zero-valent iron and ultrasonic wave with a frequency of $19.8 \mathrm{kHz}$ in this system, and the experiment of degrading tetracycline hydrochloride is completed within 30 minutes. In this experiment, zero-valent iron is characterized by SEM and XRD. The mechanism of tetracycline hydrochloride removal process by zero-valent iron should be proposed. The effects of the initial $\mathrm{pH}, \mathrm{ZVI}$ dosage, ultrasonic power and initial TCH concentration on the removal efficiency of tetracycline hydrochloride are studied in detail. In addition, a control experiment is set up to explore the synergistic effect of US and ZVI in US, ZVI and US-ZVI systems respectively. At the same
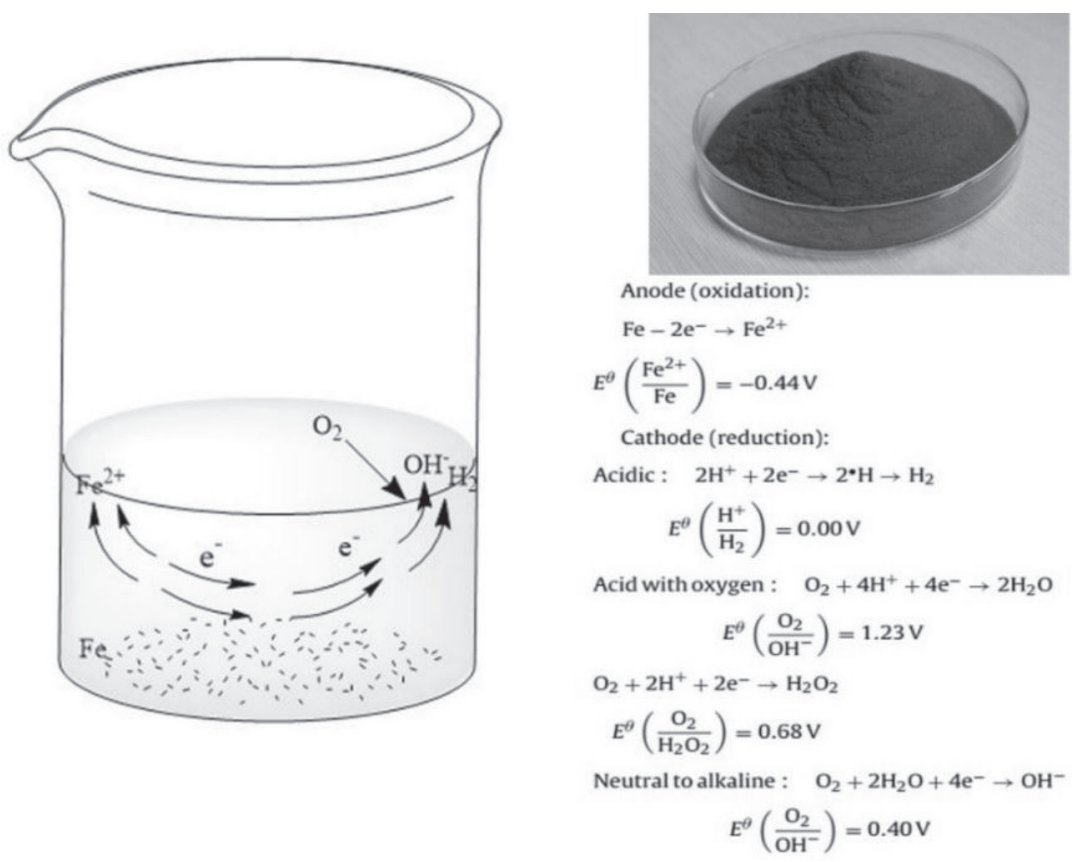

Fig. 1. Morphology of zero-valent iron and microscopic galvanic cells are formed in the interior of iron chips. 
Table 1. Physiochemical characteristics of tetracycline hydrochloride.

\begin{tabular}{|c|c|c|c|c|}
\hline Name & Structural formula & Molecular formula & Molar mass $/\left(\mathrm{g} \cdot \mathrm{mol}^{-1}\right)$ & $\begin{array}{l}\text { Maximum absorption } \\
\text { wavelength /nm }\end{array}$ \\
\hline $\begin{array}{l}\text { Tetracycline } \\
\text { hydrochloride }\end{array}$ & & $\mathrm{C}_{22} \mathrm{H}_{25} \mathrm{ClN}_{2} \mathrm{O}_{8}$ & 480.9 & 360 \\
\hline
\end{tabular}

time, the change of initial $\mathrm{pH}$ during the reaction is also measured during the experiment. Then, the recycling experiments would be carried out. Finally, according to liquid chromatography-mass spectrometry analysis, the degradation pathway of tetracycline hydrochloride should be proposed.

\section{Experimental Section}

\section{Materials and Equipment}

Tetracycline hydrochloride $(>96.0 \%$, w/w) from Chengdu Kelong chemical reagent factory was used in the experiment, which was stored at $-4^{\circ} \mathrm{C}$, and its molecular structure and main physicochemical properties are shown in Table 1. Zero-valent iron powders (mean particle size was approximately $120 \mu \mathrm{m}$, iron content reaches approximately 98\%) from Chengdu Kelong chemical reagent factory were used in the experiment. Hydrochloric acid ( $\mathrm{HCl}$, analytical grade), sodium hydroxide $(\mathrm{NaOH}$, analytical grade), nitrogen $\left(\mathrm{N}_{2}\right)$, polytetrafluoroethylene (PTFE) syringe filter disc $(0.45 \mu \mathrm{m})$, brown bottles. AE224C-SOPTOP Analytical balance (Shanghai Shun Yu Heng Ping
Scientific Instrument Co., Ltd.), AK-100ST Ultrasonic cleaning machine (Shenzhen Yujie Cleaning Equipment Co., Ltd.), JJ-1H Constant speed mechanical stirrer (Changzhou Yuexin Instrument Manufacturing Co., Ltd.), pHS-3C meter (Shanghai Youke Instrument Co., Ltd.), Deionized water machine (EKEA electronics co., ltd), UV-5100 Spectrophotometer (Shanghai Yuancheng Instrument Co., Ltd.), S-3400 N Scanning electron microscope (Hitachi Co., Japan), X-ray diffraction (XRD), IT-TOF liquid chromatography-mass spectrometry (Shimadzu Instruments (Suzhou) Co., Ltd.).

\section{Experimental Procedures}

The degradation experiments were carried out $\left(25 \pm 2^{\circ} \mathrm{C}\right)$ in an experimental device as shown in Fig. 2. Prior to each batch of experiments, the solution of $\mathrm{TCH}$ concentration under corresponding experimental conditions was prepared. Aerate with nitrogen was used to remove dissolved oxygen. The $\mathrm{pH}$ of the solution was adjusted with $0.5 \mathrm{~mol} \cdot \mathrm{L}^{-1}$ of dilute hydrochloric acid and $0.2 \mathrm{~mol} \cdot \mathrm{L}^{-1}$ of sodium hydroxide. An appropriate amount of zero-valent iron was added to the reactor containing the $\mathrm{TCH}$ solution to start the reaction,

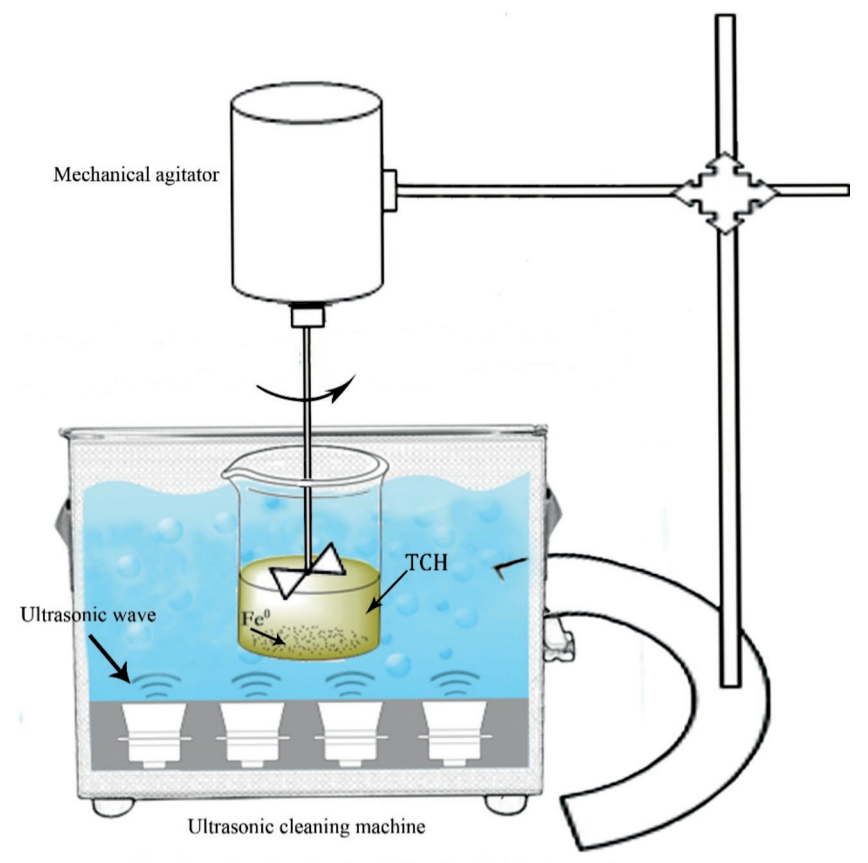

Fig. 2. Schematic diagram of mechanical agitator. 


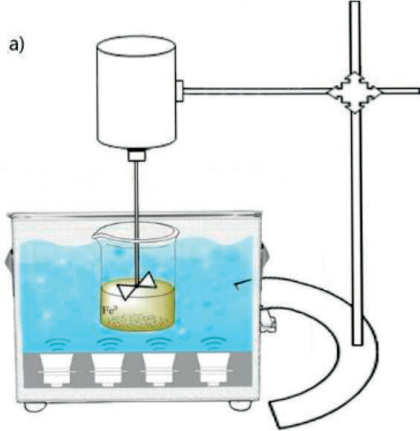

US-ZVI system

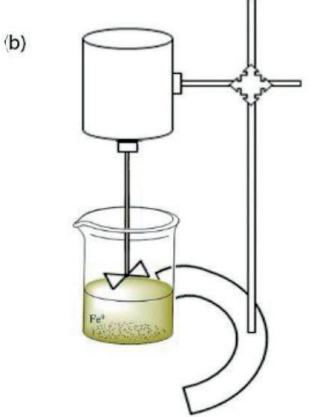

ZVI system

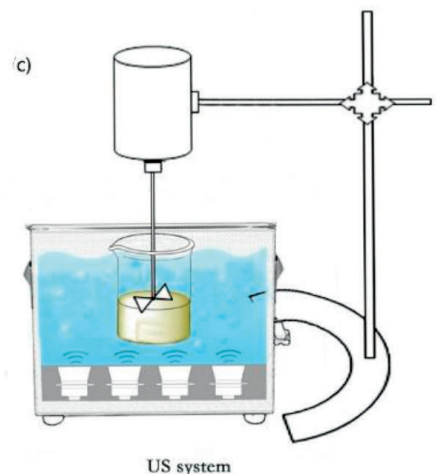

US system

Fig. 3. Experimental device diagram of synergistic reaction.
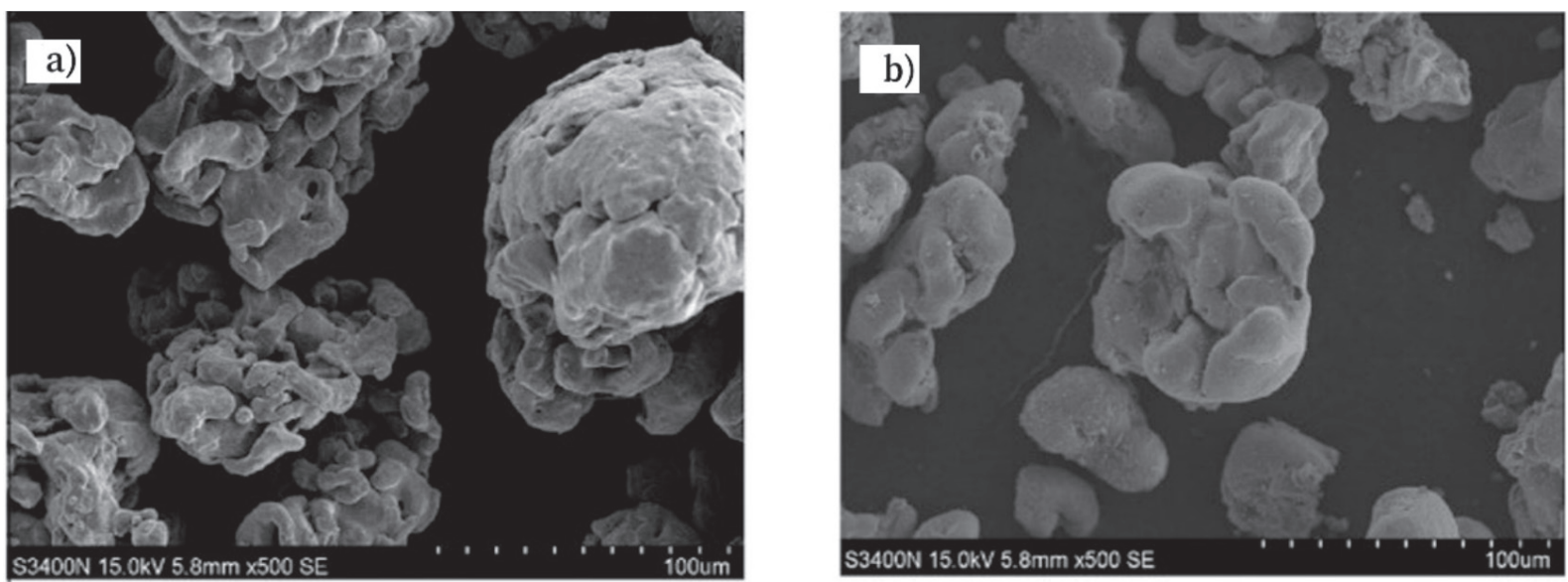

ultrasonic cracking was performed at a frequency of $19.87 \mathrm{kHz}$. The solution was stirred continuously with a non-metallic mechanical stirrer for 30 minutes to ensure the uniformity throughout the reaction. $20 \mathrm{~mL}$ of sample was taken out at regular intervals, and $0.45 \mu \mathrm{m}$ polytetrafluoroethylene (PTFE) syringe filter disc was used to remove zero-valent iron.

In this experiment, the effects of initial $\mathrm{pH}(3,5,7$, 9), ZVI dosage $\left(0.1,0.2,0.3,0.4,0.5 \mathrm{~g} \cdot \mathrm{L}^{-1}\right)$, ultrasonic power $(100,200,300,400$ and $500 \mathrm{~W})$ and initial $\mathrm{TCH}$ concentration $(10,20,30,40,50 \mathrm{ppm})$ on $\mathrm{TCH}$ removal efficiency of the US-ZVI system were studied in detail through batch experiments. In addition, three groups of experiments were set up to explore the synergistic reaction between ZVI and US (ZVI with US, ZVI without US and US without ZVI were added in the experiments respectively), the experimental device is shown in Fig. 3. Then, the collected sample was detected by UV-5100 Spectrophotometer at $360 \mathrm{~nm}$. The $\mathrm{pH}$ of the solution was measured by PHS-3C meter, and deionized water was used throughout the whole experiment process.

The degradation efficiency $\eta$ of tetracycline hydrochloride is calculated according to formula (1):

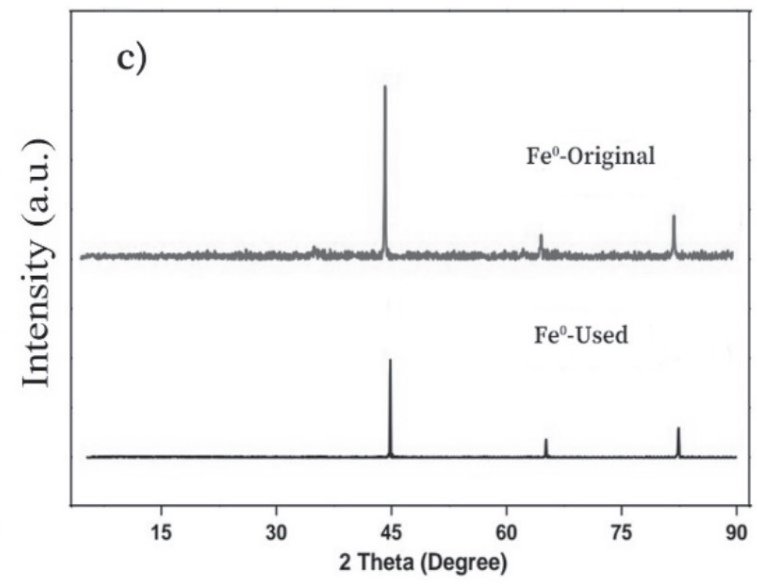

Fig. 4. SEM images of ZVI before a) and after b) reaction, and XRD pattern of ZVI c). 


$$
\eta=\frac{C_{0}-C}{C_{0}} \times 100 \%
$$

In formula, $\mathrm{C}$ is the concentration of $\mathrm{TCH}$ at time $\mathrm{t}$, and $\mathrm{C}_{0}$ is the initial $\mathrm{TCH}$ concentration.

The observed reaction rate constant $\mathrm{K}_{\text {obs }}$ is calculated according to formula (2):

$$
-K_{o b s} t=\ln \frac{C}{C_{0}}
$$

In formula, $\mathrm{C}$ is the concentration of $\mathrm{TCH}$ at time $\mathrm{t}$, and $\mathrm{C}_{0}$ is the initial $\mathrm{TCH}$ concentration, $\mathrm{t}$ is the reaction time.

\section{Results and Discussion}

\section{Characteristics of the $\mathrm{Fe}^{0}$}

The images of ZVI particles before and after reaction were observed using SEM, and the results were shown in Fig. 4a) and Fig. 4b). From Fig. 4a), it can be seen that the ZVI particles aggregated together before reaction. After reaction, the size of ZVI decreased significantly (Fig. 4b), which may be attributed to the dissolution of ZVI and ultrasonic splitting of ZVI. Besides, the surface of ZVI became rough due to the formed precipitates deposition on ZVI surface.
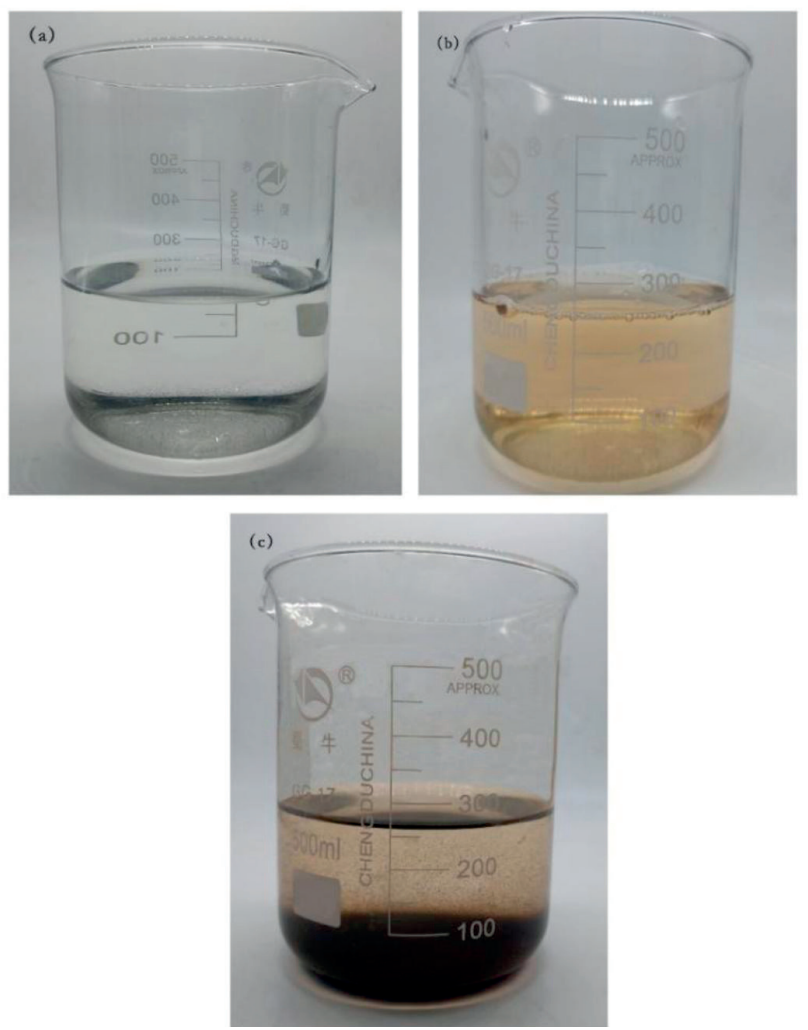

Fig. 5. Color changes of tetracycline hydrochloride during the experiment.
Fig. 4c) shows XRD pattern of ZVI particles. The XRD pattern of ZVI after reaction were compared with original ZVI. The characteristic peaks of iron appear at the diffraction angle $(2 \theta)$ of $44.8,65.2$, and 82.5 , where the main diffraction peak is at 44.8 . The characteristic peaks of ZVI after reaction were the same with original ZVI, but the intensity of peaks decreased. According to the previous study [48], the decreased intensity of peaks was attributed to the lattice strain caused by the differences of various atomic sizes.

\section{The Mechanism of Tetracycline Hydrochloride Removal Process by ZVI}

Numerous microscopic galvanic cells, which play a leading role in the degradation of the organic pollutants in wastewater in the ZVI system, are formed in the interior of iron chips because of the cementite (C). In the microscopic galvanic cell, $\mathrm{Fe}^{0}$ and cementite (C) are used as anode and cathode, respectively. And the electrons are provided by the galvanic corrosion of $\mathrm{Fe}^{0}$ (anode) [49].

Free radical $\cdot H$ produced by electrode action can reduce organic pollutants in the ZVI system under anaerobic condition [49], while the hydrogen peroxide $\left(\mathrm{H}_{2} \mathrm{O}_{2}\right)$ would be generated under aerobic condition [5052]. In addition, the produced $\mathrm{H}_{2} \mathrm{O}_{2}$ could react with the $\mathrm{Fe}^{2+}$ and generate strong oxidants such as ferric ions $\left(\mathrm{Fe}^{3+}\right)$ and hydroxyl radical $(\cdot \mathrm{OH})$ [53-55]. These strong oxidants can oxidize or mineralize organic pollutants. Furthermore, the pollutants can also be removed by enmeshment, adsorption and co-precipitation by the ferric and ferrous hydroxides formed from oxidation and precipitation of $\mathrm{Fe}^{2+}$ [49].

\section{Effects of Reaction Parameters}

In the experiment, zero-valent iron was irradiated with ultrasonic waves to remove tetracycline hydrochloride in simulated wastewater. Tetracycline hydrochloride has good water solubility and is very light in color after being dissolved in water (Fig. 5a). And the experiment was carried out under the corresponding experimental conditions, the solution first turned yellow and then became clear, and there was sediment sinking at the bottom of the beaker (Fig. 5(b-c)).

\section{Effect of Initial pH on Removal Efficiency}

Batch experiments of $20 \mathrm{ppm}$ tetracycline hydrochloride reduced using ZVI and ultrasonic irradiation were carried out at different $\mathrm{pH}$ values of 3 , 5, 7 and 9, respectively. Fig. 6a) shows the relationship between the concentration ratio $\left(\mathrm{C} / \mathrm{C}_{0}\right)$ of residual tetracycline hydrochloride in the US-ZVI system and time under different initial $\mathrm{pH}$ conditions. It is obvious that the removal efficiency of tetracycline hydrochloride is significantly reduced with the increase of initial $\mathrm{pH}$. When the initial $\mathrm{pH}$ was increased from 3 to 9, 

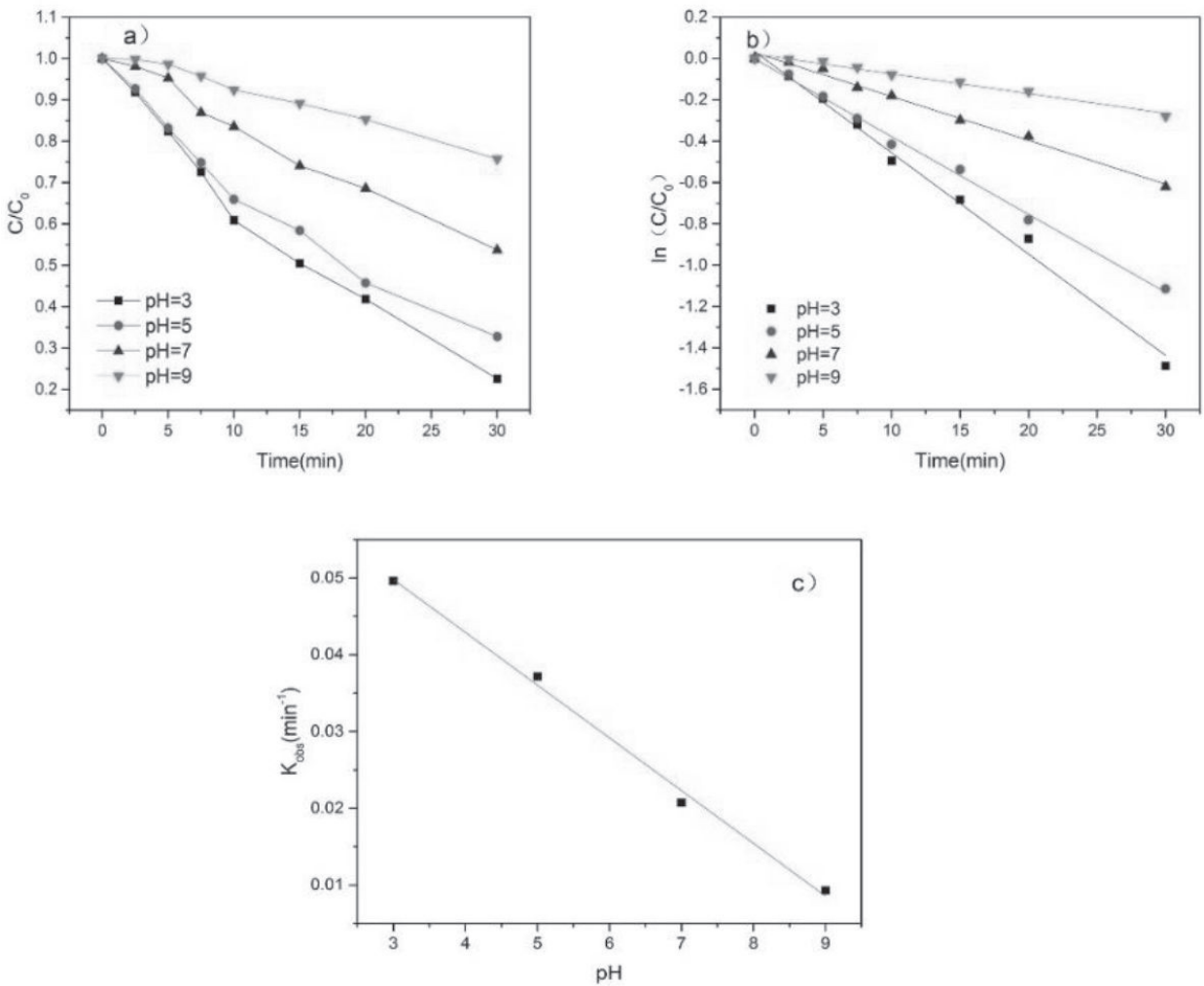

Fig. 6. Effect of the initial $\mathrm{pH}$ on the removal of Tetracycline hydrochloride by US-ZVI ([tetracycline hydrochloride]: $20 \mathrm{ppm}$, [Fe $\left.{ }^{0}\right]$ : $0.4 \mathrm{~g} \cdot \mathrm{L}^{-1}$, frequency: $19.87 \mathrm{kHz}$, power: $400 \mathrm{~W}$, volume: $250 \mathrm{~mL}$, temperature: $25 \pm 2^{\circ} \mathrm{C}$ ).
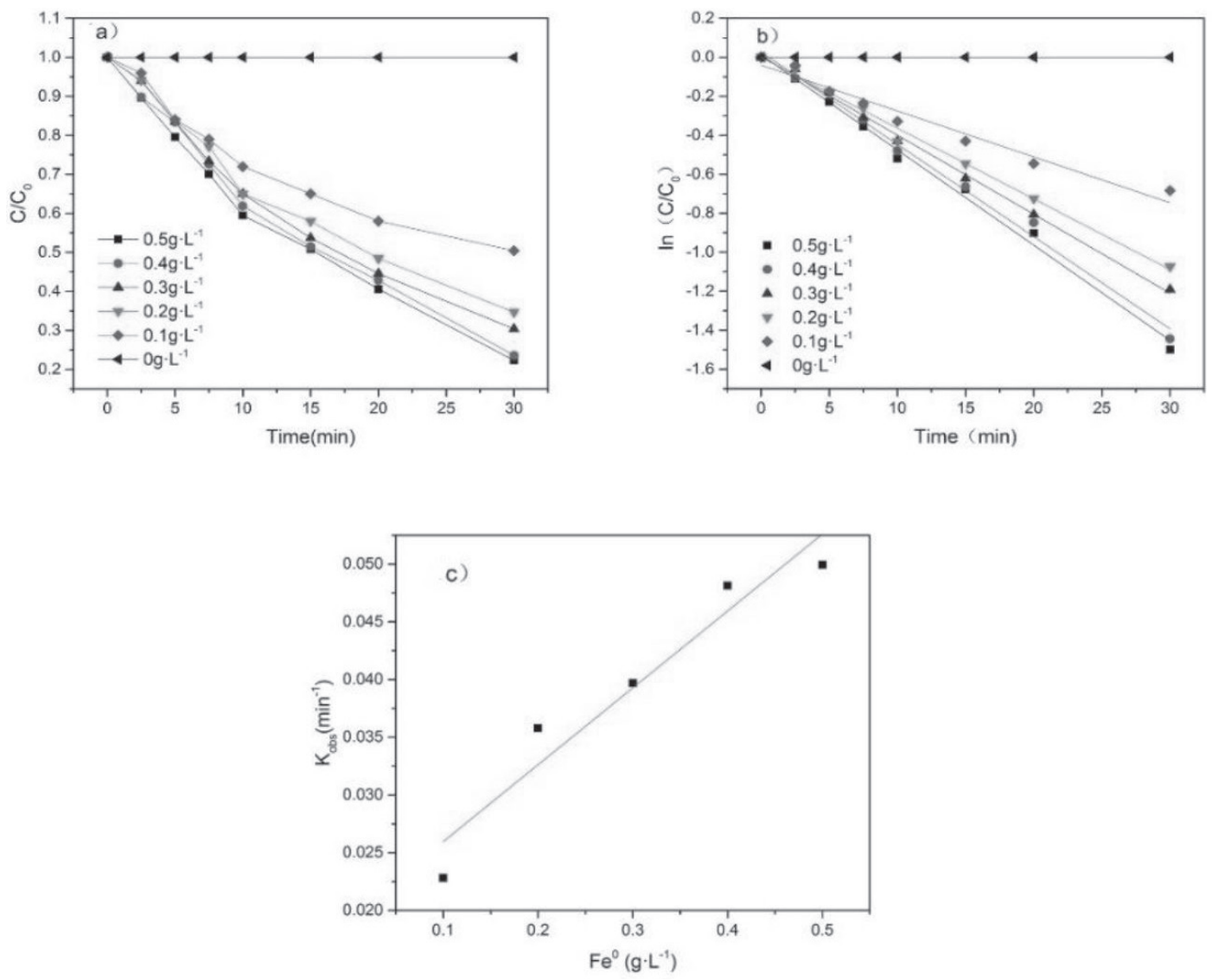

Fig. 7. Effect of the ZVI dosage on the removal of Tetracycline hydrochloride by US-ZVI ([tetracycline hydrochloride]: $20 \mathrm{ppm}$, initial pH 3.0, frequency: $19.87 \mathrm{kHz}$, power: $400 \mathrm{~W}$, volume: $200 \mathrm{~mL}$, temperature: $25 \pm 2^{\circ} \mathrm{C}$ ). 
the removal rate of tetracycline hydrochloride was decreased from $76.4 \%$ to $24.3 \%$. Fig. 6 b) shows that the reduction of tetracycline hydrochloride with different initial $\mathrm{pH}$, and it demonstrates that all of them obeyed the pseudo first-order kinetics mode. In addition, when the initial $\mathrm{pH}$ was raised from 3 to 9, the observed reaction rate constant $\left(\mathrm{K}_{\text {obs }}\right)$ decreased from 0.04958 to 0.009283 . Fig. 6c) shows that the values of $\mathrm{K}_{\mathrm{obs}}$ for tetracycline hydrochloride reduction decrease with the increase of initial $\mathrm{pH}$. The $\mathrm{K}_{\mathrm{obs}}$ has a good linear relationship with the initial $\mathrm{pH}$ and the correlation of determination $\left(\mathrm{R}^{2}\right)$ reaches 0.9954. And the kinetic expression is as follows:

$$
\mathrm{K}_{o b s}=-0.0069(p H)+0.0704\left(R^{2}=0.9954\right)
$$

Therefore, it can be known through experiment that the $\mathrm{pH}$ is in the range of 3-9, the lower initial $\mathrm{pH}$ $(3,5)$ can accelerate the removal rate of tetracycline hydrochloride by the US-ZVI system, and the higher initial $\mathrm{pH}$ (9) slows down the removal rate of tetracycline hydrochloride by the US-ZVI system. In addition, when the $\mathrm{pH}$ of the tetracycline hydrochloride solution is less than 7, the $\mathrm{pH}$ of the tetracycline hydrochloride solution slowly increases throughout the experiment, and free radical $\cdot \mathrm{H}$ are consumed. However, when the $\mathrm{pH}$ of tetracycline hydrochloride solution is more than
7, the $\mathrm{pH}$ of tetracycline hydrochloride solution slowly decreases during the whole experiment. It is obvious that the initial $\mathrm{pH}$ is an important parameter affecting the process of reducing tetracycline hydrochloride in the US-ZVI system. According to previous studies [56, 57], it can be known that the stronger the acidity is, the faster the corrosion rate of $\mathrm{Fe}^{0}$ will be, thus generating a large number of free radical $\cdot H$ with strong reducibility and nascent $\mathrm{Fe}^{2+}$. Then tetracycline hydrochloride can be rapidly reduced.

\section{Effect of ZVI Dosage on Removal Efficiency}

In order to explore the effect of ZVI dosage on the removal of tetracycline hydrochloride, batch experiments of $20 \mathrm{ppm}$ tetracycline hydrochloride were carried out at different initial dosages of ZVI (0.1, 0.2, $\left.0.3,0.4,0.5 \mathrm{mg} \cdot \mathrm{L}^{-1}\right)$. Fig. 7a) shows the relationship between the concentration ratio $\left(\mathrm{C} / \mathrm{C}_{0}\right)$ of residual tetracycline hydrochloride in the US-ZVI system and time under different ZVI dosages. Obviously, when the initial zero-valent iron concentration was increased from $0.1 \mathrm{~g} \cdot \mathrm{L}^{-1}$ to $0.5 \mathrm{~g} \cdot \mathrm{L}^{-1}$, the removal efficiency of tetracycline hydrochloride was increased from $49.6 \%$ to $77.6 \%$. However, the removal efficiency is not obvious at $0.3-0.5 \mathrm{~g} \cdot \mathrm{L}^{-1}$. Fig. $7 \mathrm{~b}$ ) shows that the reduction of tetracycline hydrochloride with different ZVI dosage,
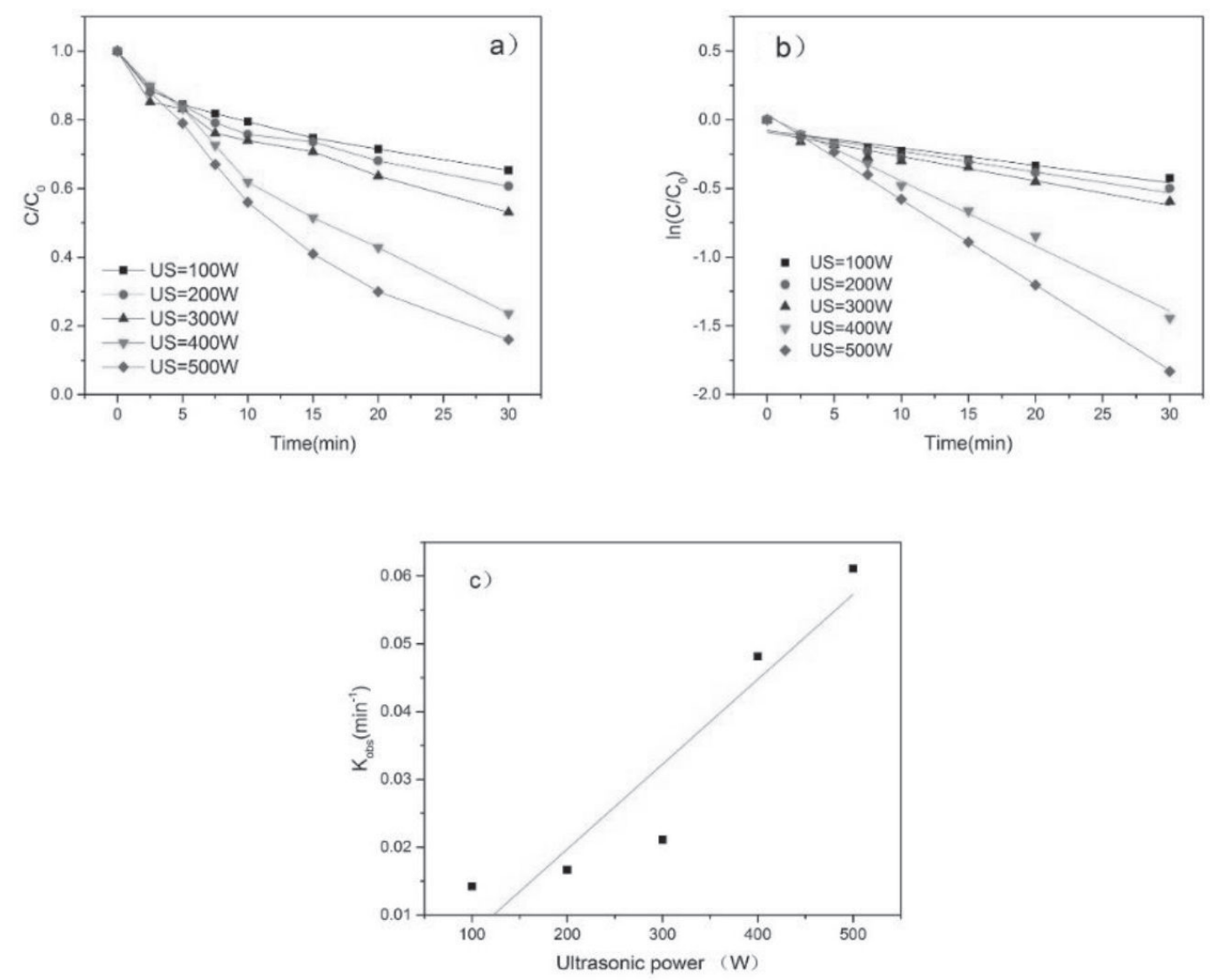

Fig. 8. Effect of ultrasonic power on the removal of Tetracycline hydrochloride by US-ZVI ([tetracycline hydrochloride]: $20 \mathrm{ppm}$, [Fe ${ }^{0}$ : $0.4 \mathrm{~g} \cdot \mathrm{L}^{-1}$, initial $\mathrm{pH} 3.0$, frequency: $19.87 \mathrm{kHz}$, volume: $200 \mathrm{~mL}$, temperature: $25 \pm 2^{\circ} \mathrm{C}$ ). 
and it demonstrates that all of them obeyed the pseudo first-order kinetics mode. In addition, when the initial ZVI dosage increased from $0.1 \mathrm{~g} \cdot \mathrm{L}^{-1}$ to $0.5 \mathrm{~g} \cdot \mathrm{L}^{-1}$, the observed reaction rate constant $\left(\mathrm{K}_{\mathrm{obs}}\right)$ increased from 0.02281 to 0.04994 . Fig. $7 c$ ) shows that the values of $\mathrm{K}_{\mathrm{obs}}$ for tetracycline hydrochloride increase as the ZVI dosage increases. The $\mathrm{K}_{\mathrm{obs}}$ has a good linear relationship with the initial ZVI dosage, indicating that the $\mathrm{K}_{\mathrm{obs}}$ is proportional to the concentration of ZVI. And the correlation of determination $\left(\mathrm{R}^{2}\right)$ reaches 0.9327 . The kinetic expression can be expressed as follows:

$$
K_{\text {obs }}=0.0666(Z V I)+0.0193\left(R^{2}=0.9327\right)
$$

Obviously, the results show that the initial zerovalent iron dosage is a factor affecting the process of reducing tetracycline hydrochloride in the USZVI system, the removal efficiency of tetracycline hydrochloride can be increased with the increase of the initial zero-valent iron dosage from $0.1 \mathrm{~g} \cdot \mathrm{L}^{-1}$ to $0.5 \mathrm{~g} \cdot \mathrm{L}^{-1}$. Since the total surface area of ZVI increases with the increase of the initial ZVI concentration,
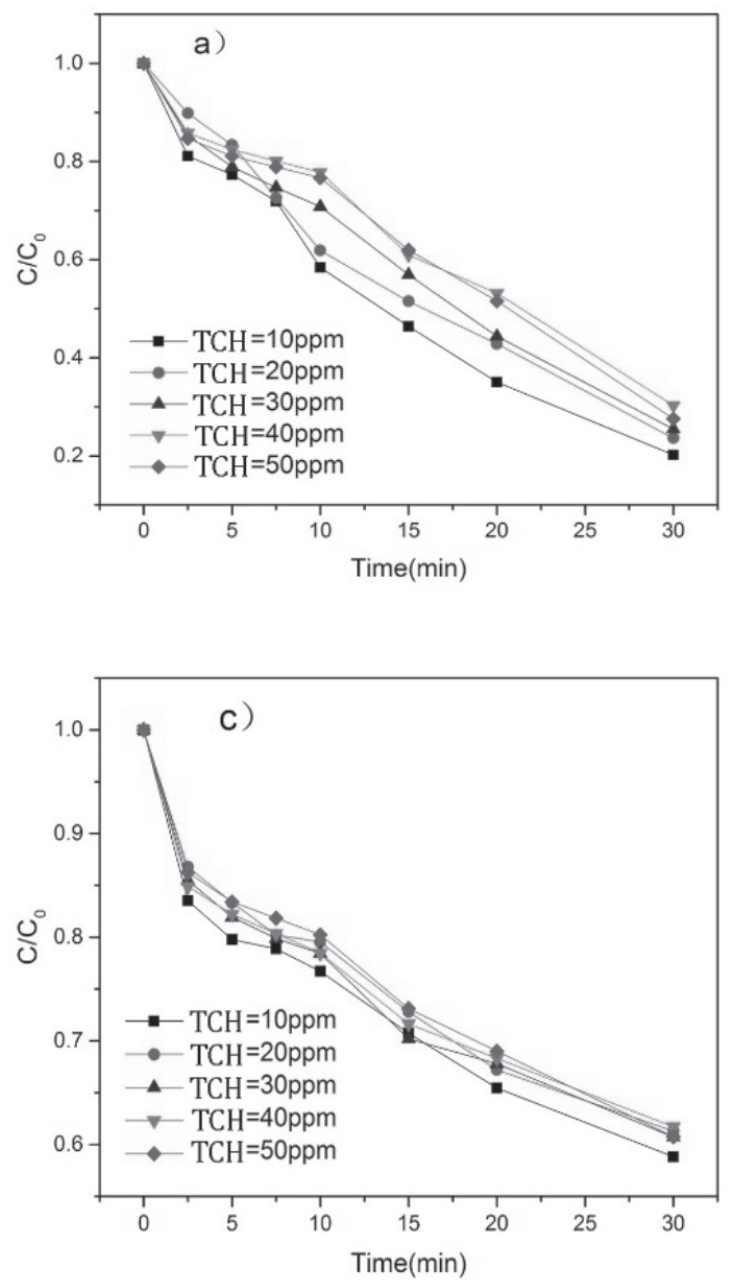

the mass transfer rate of intermediates, products and reactants in the solution phase with the $\mathrm{Fe}^{0}$ surface increases [58, 59], and the reduction of $\mathrm{Fe}^{0}$ is enhanced. In addition, $\mathrm{Fe}^{0}$ has electrochemical characteristics. The increase of ZVI concentration leads to the increase of free radical $\cdot \mathrm{H}$ and new $\mathrm{Fe}^{2+}$ in the products of electrode reaction $[60,61]$, and can also accelerate the reduction of tetracycline hydrochloride.

\section{Effect of Ultrasonic Power on Removal Efficiency}

In order to study the effect of ultrasonic power on the tetracycline hydrochloride reduction, batch experiments were performed on a condition that different ultrasonic power $(100,200,300,400,500 \mathrm{~W})$ were used to treat $20 \mathrm{ppm}$ of tetracycline hydrochloride solutions with initial $\mathrm{pH}$ 3. Fig. 8a) shows the relationship between the concentration ratio $\left(\mathrm{C} / \mathrm{C}_{0}\right)$ of residual tetracycline hydrochloride in the US-ZVI system and time under different ultrasonic power. The results show that the removal efficiency of tetracycline hydrochloride increased with the increase of ultrasonic power from
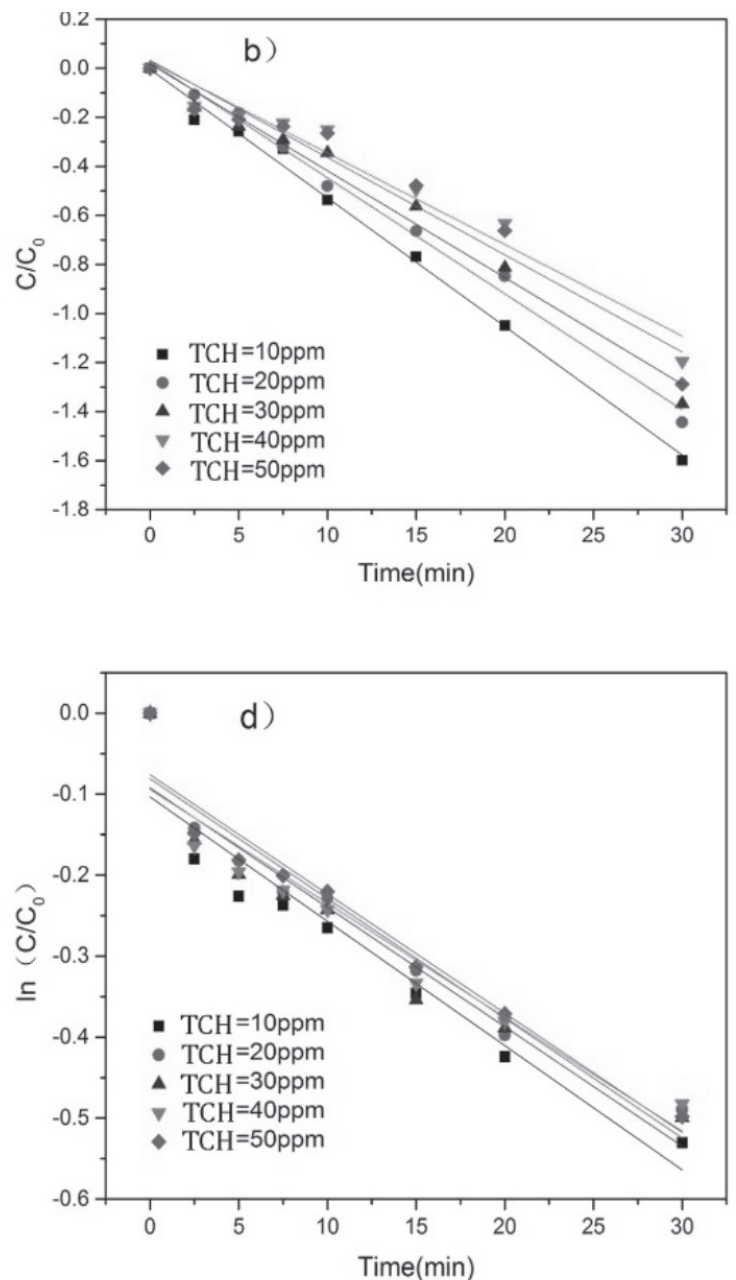

Fig. 9. Effect of the initial TCH concentration on the removal of tetracycline hydrochloride by US-ZVI ([Fe $]: 0.4 \mathrm{~g} \cdot \mathrm{L}^{-1}$, initial $\mathrm{pH} 3.0$, frequency: $19.87 \mathrm{kHz}$, power: $400 \mathrm{~W}$, volume: $250 \mathrm{~mL}$, temperature: $\left.25 \pm 2^{\circ} \mathrm{C}\right)$ or $\mathrm{ZVI}\left(\left[\mathrm{Fe}^{0}\right]: 0.4 \mathrm{~g} \cdot \mathrm{L}^{-1}\right.$, initial $\mathrm{pH} 3.0$, volume: $250 \mathrm{~mL}$, temperature: $\left.25 \pm 2^{\circ} \mathrm{C}\right)$. 
$100 \mathrm{~W}$ to $500 \mathrm{~W}$. In addition, when the ultrasonic power was increased from $100 \mathrm{~W}$ to $300 \mathrm{~W}$, the ultrasonic wave had little effect on the efficiency of the US-ZVI system for degrading tetracycline hydrochloride. When the ultrasonic power was increased from $300 \mathrm{~W}$ to $400 \mathrm{~W}$, its removal efficiency increased from $46.7 \%$ $(300 \mathrm{~W})$ to $76.4 \%(400 \mathrm{~W})$. Fig. $8 \mathrm{~b})$ shows that $\ln \left(\mathrm{C} / \mathrm{C}_{0}\right)$ has a good linear relationship with time. When the initial ultrasonic power was increased from $100 \mathrm{~W}$ to $500 \mathrm{~W}$, the observed reaction rate constant $\left(\mathrm{K}_{\mathrm{obs}}\right)$ increased from 0.01420 to 0.06109 . The results show that ZVI particles could not be fluidized by ultrasonic turbulence at low ultrasonic power $(\leq 300 \mathrm{~W})$, the removal rate of tetracycline hydrochloride is below $46.7 \%$, but at high ultrasonic power $(\geq 400 \mathrm{~W})$, the removal rate of tetracycline hydrochloride is as high as $76.4 \%$ in the 30-minute treatment process. Fig. 8c) shows that the values of $\mathrm{K}_{\mathrm{obs}}$ for tetracycline hydrochloride reduction increase with the increase of the initial ultrasonic power and the correlation of determination $\left(\mathrm{R}^{2}\right)$ reaches 0.8825 . When the ultrasonic power is increased from $300 \mathrm{~W}$ to $400 \mathrm{~W}, \mathrm{~K}_{\mathrm{obs}}$ has a large increasing trend.

The results show that ultrasonic power is also an important factor affecting tetracycline hydrochloride degradation. Since the lifetime of the free radical $\cdot H$ produced by the microscopic primary battery on the surface of the ZVI particle is very short $[62,63]$, the reduction process of tetracycline hydrochloride mainly occurs on the surface of the ZVI particle. Adding ultrasonic wave can improve the mixing intensity of the US-ZVI system [64], in addition to the mass transport rates between intermediates, products and reactants and $\mathrm{Fe}^{0}$ surface, which can also be accelerated $[58,59]$, thus accelerating the chemical reaction on the surface of zero-valent iron.

\section{Effect of TCH Concentration on Removal Efficiency}

In order to investigate the effect of concentration on the tetracycline hydrochloride removal by the
US-ZVI system, batch experiments were carried out at different initial TCH concentrations of 10, 20, 30, 40, $50 \mathrm{ppm}$, respectively. Fig. 9a) shows the relationship between the concentration ratio $\left(\mathrm{C} / \mathrm{C}_{0}\right)$ of residual tetracycline hydrochloride in the US-ZVI system and time under different $\mathrm{TCH}$ concentration, and shows the effect of the initial TCH concentration on the tetracycline hydrochloride removal efficiency of the US-ZVI system. It is indicated that the residual tetracycline hydrochloride was maintained between $20 \%$ and $30 \%$ after treatment with the US-ZVI system under different initial TCH concentrations of 10, 20, 30, 40 and $50 \mathrm{ppm}$. The removal efficiency of tetracycline hydrochloride at different concentrations in the US-ZVI system can be described by a pseudo firstorder reaction. Fig. $9 b)$ shows that $\ln \left(\mathrm{C} / \mathrm{C}_{0}\right)$ has a good linear relationship with time, and all the correlation of determination $\left(\mathrm{R}^{2}\right)$ are larger than 0.95 . When the initial $\mathrm{TCH}$ concentration was increased from $10 \mathrm{ppm}$ to $50 \mathrm{ppm}$, the observed reaction rate constant $\left(\mathrm{K}_{\mathrm{obs}}\right)$ basically remained between 0.04 and 0.05 , indicating that the concentration of tetracycline hydrochloride can hardly affect the removal ability of tetracycline hydrochloride by the US-ZVI system.

However, Fig. 9c) shows the relationship between the concentration ratio $\left(\mathrm{C} / \mathrm{C}_{0}\right)$ of residual tetracycline hydrochloride in the ZVI system and time under different initial tetracycline hydrochloride concentration. After 30 minutes of treatment, the ZVI system has low removal efficiency for tetracycline hydrochloride. The removal rate of tetracycline hydrochloride in the ZVI system is always maintained at about $40 \%$. Fig. 9d) shows that $\ln \left(\mathrm{C} / \mathrm{C}_{0}\right)$ has a good linear relationship with time, and all the correlation of determination $\left(\mathrm{R}^{2}\right)$ are larger than 0.91. Although the initial concentration of tetracycline hydrochloride increased from $10 \mathrm{ppm}$ to $50 \mathrm{ppm}$, the removal efficiency was hardly affected by the initial concentration of tetracycline hydrochloride.

Therefore, the results show that when the initial concentration of tetracycline hydrochloride is $10,20,30$,

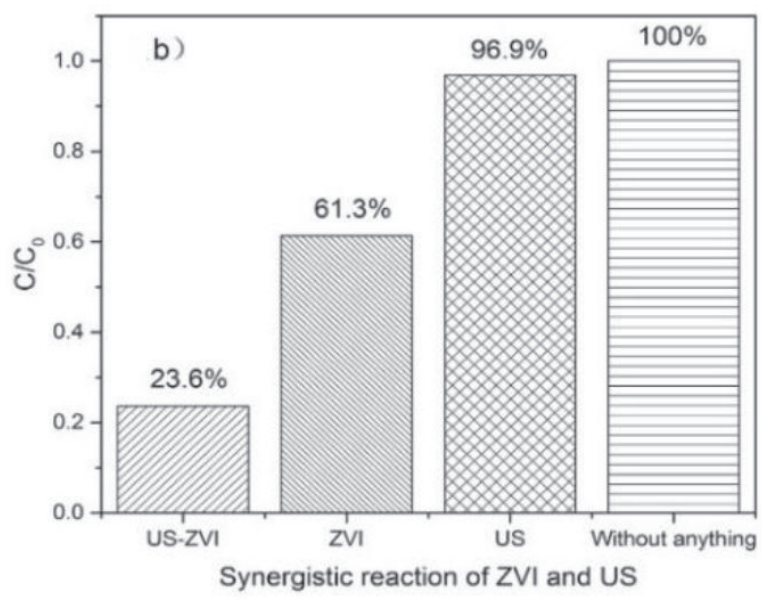

Fig. 10. Variation of TCH removal efficiencies in the three different experiments ([tetracycline hydrochloride]: $20 \mathrm{ppm}$, initial pH 3.0 , volume: $250 \mathrm{~mL}$, temperature: $25 \pm 2^{\circ} \mathrm{C}$ ). 


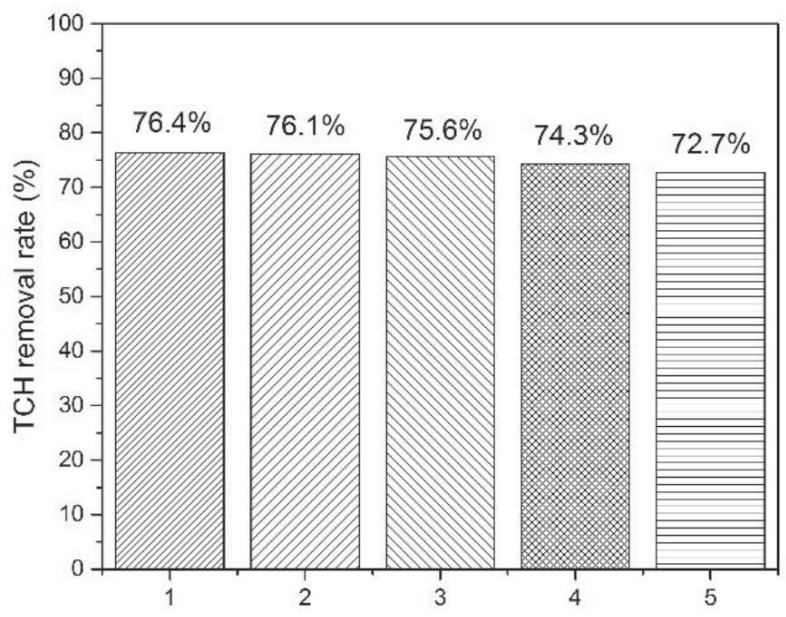

Recycing of zero-valent iron after five experiments

Fig. 11. Recycling of zero-valent iron ([tetracycline hydrochloride]: $20 \mathrm{ppm},\left[\mathrm{Fe}^{0}\right]: 0.4 \mathrm{~g} \cdot \mathrm{L}^{-1}$, initial $\mathrm{pH} 3.0$, frequency: $19.87 \mathrm{kHz}$, power: $400 \mathrm{~W}$, volume: $250 \mathrm{~mL}$, temperature: $\left.25 \pm 2^{\circ} \mathrm{C}\right)$.

40, $50 \mathrm{ppm}$, the initial concentration can hardly affect the removal efficiency of tetracycline hydrochloride by US-ZVI system and ZVI system, but the removal efficiency of tetracycline hydrochloride by zero-valent iron can be improved by ultrasonic irradiation.

\section{Removal of TCH by Synergistic Reaction of ZVI and US}

Tetracycline hydrochloride was degraded by different systems. Fig. 10a) shows the degradation process of tetracycline hydrochloride under different experimental conditions of US-ZVI, ZVI and US system. Fig. 10a) also shows the time courses of residual tetracycline hydrochloride concentration ratios $\left(\mathrm{C} / \mathrm{C}_{0}\right)$ in the US-ZVI, ZVI and US system. Obviously, it shows that the US-ZVI system has the best removal efficiency of tetracycline hydrochloride, and the US system has the lowest removal efficiency of tetracycline hydrochloride. Obviously, after 30 minutes of reaction, Fig. 10b) shows that the removal efficiency of tetracycline hydrochloride by the US-ZVI system (76. 4\%) is higher than that by the ZVI system (39.7\%), and the US system can hardly degrade tetracycline hydrochloride, and its degradation rate is only $3.1 \%$.

Therefore, the higher removal efficiency of tetracycline hydrochloride by the US-ZVI system is mainly due to the enhancement of ZVI by ultrasonic irradiation. ZVI particles could be fluidized completely by ultrasonic irradiation [65], and the mass transport rates of intermediates, products and reactants between the solution phase and the $\mathrm{Fe}^{0}$ surfaces are increased [58, 59]. In addition, ultrasonic radiation can remove iron contaminants and corrosion products deposited
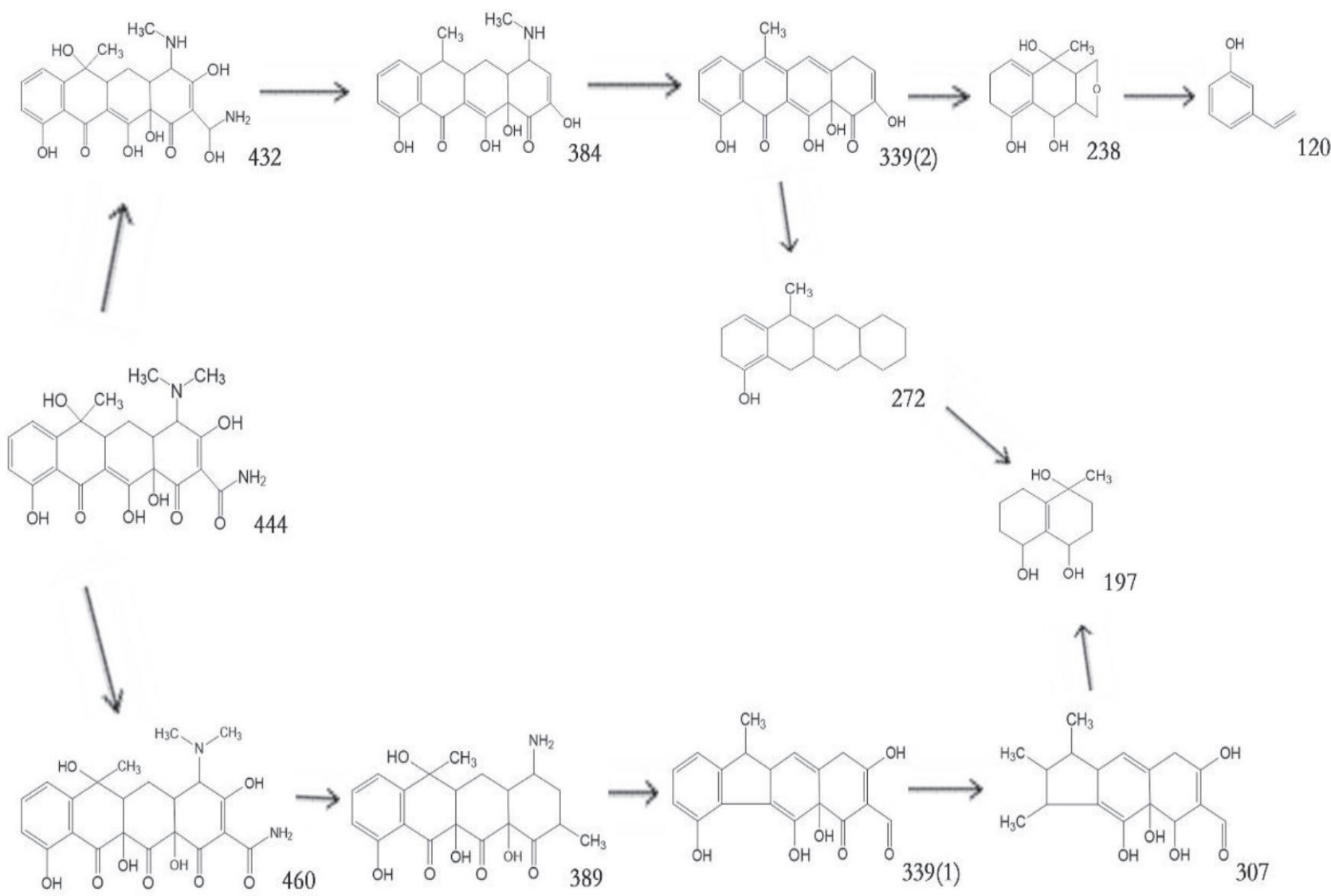

Fig. 12. Proposed degradation pathway of TCH and the chemical structure of intermediates. 
on the surface of ZVI particles, and can also avoid the formation of concentration polarization. The surface activity of the ZVI particles are maintained in the solution phase, and the reduction of $\mathrm{Fe}^{0}$ is enhanced.

Recycling of Zero-Valent Iron

The reusable potential of $\mathrm{Fe}^{0}$ was studied through five repeated experiments. Fig. 11 shows that the removal efficiency of tetracycline hydrochloride by the US-ZVI system decreased slightly (3.7\%) after five repeated experiments. $\mathrm{Fe}^{0}$ was recovered after washing and drying, the mass of $\mathrm{Fe}^{0}$ was $93.2 \%$ of that before reaction and the loss mass was $6.8 \%$. It can be seen that the removal rate of tetracycline hydrochloride by the US-ZVI system shows a downward trend with the increase of recycling times, but it has a low decreasing trend. Although, the removal rate of tetracycline hydrochloride was reduced by about $4 \%$ after five experiments, but zero-valent iron still has good catalytic effect.

\section{Degradation Pathway of TCH}

According to liquid chromatography-mass spectrometry results, the main degradation intermediates of TCH by ZVI are listed in Fig. 12. According to previous studies, oxidation is the main removal route of tetracycline hydrochloride using zero-valent iron under acidic conditions. Most of tetracycline hydrochloride are degraded to kinds of intermediates and a part of those intermediates would be decomposed to $\mathrm{CO}_{2}, \mathrm{H}_{2} \mathrm{O}$ and inorganic ions $\left(\mathrm{NO}_{3}^{-}, \mathrm{NH}_{4}^{+}\right)$. The degradation pathway of tetracycline hydrochloride is shown in Fig. 12, amino group, ketone group, aromatic ring and double bond are reactive sites $[27,66]$. In the first step of the reaction, two main intermediates with $\mathrm{m} / \mathrm{z}$ (mass-to-charge ratio) of 460 and 432 are generated and there are two degradation pathways: (1) The intermediate with $\mathrm{m} / \mathrm{z}$ of 460 is originated from the hydroxylation reaction of tetracycline hydrochloride by the electrophilic addition of $\mathrm{HO}$ to the aromatic ring forms a resonancestabilized carbon-centered radical, this could lead to the disappearance of tetracycline hydrochloride band in $360 \mathrm{~nm}[67,68]$. Then, by losing two N-methyl groups, a methyl group, a hydroxyl group and an amino group, the intermediate with $\mathrm{m} / \mathrm{z}$ of 389 is generated from product with $\mathrm{m} / \mathrm{z}$ of 460 . The intermediate product with $\mathrm{m} / \mathrm{z}$ of $339(1)$ is generated from the product with $\mathrm{m} / \mathrm{z}$ of 389 through decarbonylation and hydroxylation [69]. The intermediate with $\mathrm{m} / \mathrm{z}$ of 339 generates intermediate with $\mathrm{m} / \mathrm{z}$ of 307 through cleavage of C-C double bond in aromatic ring $[66,70]$. (2) Due to the low bond energy of N-C [71], the N-demethylation process produces tetracycline hydrochloride intermediate with $\mathrm{m} / \mathrm{z}$ of 432 . After $\mathrm{H}$-abstraction, a radical ion is formed. A hydroxyl group attached to this radical ion, promoting the hydrolysis and the generation of intermediate with $\mathrm{m} / \mathrm{z}$ of 432 [72]. By losing a N-methyl group, a methyl group and two hydroxyl groups, the intermediate with $\mathrm{m} / \mathrm{z}$ of 384 is formed from product with $\mathrm{m} / \mathrm{z}$ of 432 . The intermediate with $\mathrm{m} / \mathrm{z}$ of $339(2)$ is generated from product with $\mathrm{m} / \mathrm{z}$ of 384 through deamination [70]. Intermediate with $\mathrm{m} / \mathrm{z}$ of 272 is formed from 339(2) via the loss of hydroxyl groups [73]. The cleavage of double bond in aromatic ring produced intermediate product with $\mathrm{m} / \mathrm{z}$ of 238 [66]. Finally, the intermediate products with $\mathrm{m} / \mathrm{z}$ of 197 and 120 generated via ring-opening reactions and dislodging hydroxyl or methyl groups [74, 75]. Among them, the product with $\mathrm{m} / \mathrm{z}$ of 339(2) and the product with $\mathrm{m} / \mathrm{z}$ of 339(1) are intermediate products in two forms.

\section{Conclusions}

The tetracycline hydrochloride simulated wastewater was treated by the US-ZVI system. We showed that the treatment efficiency would be affected by the initial $\mathrm{pH}, \mathrm{ZVI}$ dosage, ultrasonic power and initial $\mathrm{TCH}$ concentration. The results show that the observed reaction rate constant $\left(\mathrm{K}_{\mathrm{obs}}\right)$ would decrease from 0.04958 to 0.009283 when the initial $\mathrm{pH}$ was decreased from 3 to 9, and it suggests that the lower initial $\mathrm{pH}$ can help to accelerate the removal rate of tetracycline hydrochloride by the US-ZVI system. Additionally, the $\mathrm{K}_{\text {obs }}$ would increase from 0.02281 to 0.04994 when the initial concentration of ZVI was increased from 0.1 to $0.5 \mathrm{~g} \cdot \mathrm{L}^{-1}$. Furthermore, the $\mathrm{K}_{\mathrm{obs}}$ of tetracycline hydrochloride at ultrasonic power of $500 \mathrm{~W}$ could reach 0.06109 which was about 4 times higher than that of tetracycline hydrochloride at ultrasonic power of 100 W. The tetracycline hydrochloride removal efficiencies all were more than $70 \%$ after 30 min treatment by the US-ZVI system under the conditions of different initial tetracycline hydrochloride concentration of 10, 20, 30, 40 and 50 ppm.

It is clear that the tetracycline hydrochloride removal efficiency of US-ZVI (76.4\%) was higher than that of ZVI (39.7\%) after $30 \mathrm{~min}$ reaction, and the tetracycline hydrochloride could hardly be removed by the US (3.1\%). The results suggest that the removal efficiency of tetracycline hydrochloride mainly resulted from the synergistic reaction of ZVI and US. Then, the recycling experiments were carried out, the result shows that zero-valent iron still has good catalytic effect after repeated use. Finally, according to liquid chromatography-mass spectrometry results, the degradation pathway of tetracycline hydrochloride was proposed.

\section{Acknowledgements}

This work was supported by China Postdoctoral Science Foundation (2017M610598, 2018T110963), and the State Key Laboratory of Geohazard Prevention and Geoenvironment Protection Foundation (SKLGP2018Z007), the National Key Research and 
Development Program of China (2018YFC0214004) and project of Education Department in Sichan(18ZB0064), Sichuan science and technology support project (2020YJ0148,2018JY0518).

\section{Conflict of Interest}

The authors declare no conflict of interest.

\section{References}

1. MACHEDA G., LUC A., BÉRAUD G., CASTAN B., GAUZIT R., LESPRIT P., TATTEVIN P., THILLY N., PULCINI C. Impact of the French Infectious Diseases Society's (SPILF) proposals for shorter antibiotic therapies. Médecine et Maladies Infectieuses, 49 (6), 456, 2019.

2. DUARTE R., FUHRICH D., ROSS J.D.C. A review of antibiotic therapy for pelvic inflammatory disease. International Journal of Antimicrobial Agents, 46 (3), 272, 2015.

3. SKAPINYECZ J., SMID I., JUHÁSZ Á., JENEY C., ROZGONYI F., KOVÁCS P. Planning of empirical antibiotic therapy for women with pelvic inflammatory diseases: a geographical area-specific study. European Journal of Obstetrics \& Gynecology and Reproductive Biology, 111 (2), 183, 2003.

4. RAHIMI R., NIKFAR S., REZAIE A., ABDOLLAHI M. A meta-analysis of broad-spectrum antibiotic therapy in patients with active Crohn's disease. Clinical Therapeutics, 28 (12), 1983, 2006.

5. LORROT M., GILLET Y., GRAS LE GUEN C., LAUNAY E., COHEN R., GRIMPREL E. Antibiotic therapy of bone and joint infections in children: proposals of the French Pediatric Infectious Disease Group. Archives de Pédiatrie, 24 (12, Supplement), S36, 2017.

6. KUHN M., GRAVE S., BRANSFIELD R., HARRIS S. Long term antibiotic therapy may be an effective treatment for children co-morbid with Lyme disease and Autism Spectrum Disorder. Medical Hypotheses, 78 (5), 606, 2012.

7. KOH W.-J., JEONG B.-H., JEON K., KIM S.-Y., PARK K.U., PARK H.Y., HUH H.J., KI C.-S., LEE N.Y., LEE S.-H., KIM C.K., DALEY C.L., SHIN S.J., KIM H., KWON O.J. Oral Macrolide Therapy Following Short-term Combination Antibiotic Treatment of Mycobacterium massiliense Lung Disease. Chest, 150 (6), 1211, 2016

8. CUNHA C.B., CUNHA B.A. Antimicrobial Therapy for Legionnaire's Disease: Antibiotic Stewardship Implications. Infectious Disease Clinics of North America, 31 (1), 179, 2017.

9. CUNHA C.B. Antibiotic Stewardship Program Perspective: Oral Antibiotic Therapy for Common Infectious Diseases. Medical Clinics of North America, 102 (5), 947, 2018.

10. BRETON J., ARTHUR K., NATALIE H., NAOMI P., LINDSAY W., RACHEL R., KELSEN J.R., BALDASSANO R.N., ALBENBERG L. Tu1869 - Efficacy of Combination Antibiotic Therapy for Refractory Pediatric Inflammatory Bowel Disease. Gastroenterology, 154 (6, Supplement 1), 1043, 2018.
11. CUNHA C.B. Antibiotic Stewardship Program Perspective : Oral Antibiotic Therapy for Common Infectious Diseases. Medical Clinics of North America, 102 S0025712518300440, 2018.

12. LEKAGUL A., TANGCHAROENSATHIEN V., YEUNG S. Patterns of antibiotic use in global pig production: A systematic review. Veterinary and Animal Science, 7, 100058, 2019.

13. WANG Q., DUAN Y.-J., WANG S.-P., WANG L.-T., HOU Z.-L., CUI Y.-X., HOU J., DAS R., MAO D.-Q., LUO Y. Occurrence and distribution of clinical and veterinary antibiotics in the faeces of a Chinese population. Journal of Hazardous Materials, 383, 121129, 2020.

14. SANGANYADO E., GWENZI W. Antibiotic resistance in drinking water systems: Occurrence, removal, and human health risks. Science of The Total Environment, 669, 785, 2019.

15. CURRIE J., LIN W., MENG J. Addressing antibiotic abuse in China: An experimental audit study. Journal of Development Economics, 110, 39, 2014.

16. BI P., TONG S., PARTON K.A. Family self-medication and antibiotics abuse for children and juveniles in a Chinese city. Social Science \& Medicine, 50 (10), 1445, 2000.

17. ABDEL GAWAD ELMASRY A., SAMIR MOHAMED BAKR A., ALAAELDIN ABDOU ABDELAZIZ KOLKAILAH D., ALMOHAMADY IBRAHIM KHASKIA M., ESSAM ELDIN MOHAMMED M., HATEM MOHAMED AMIN RIAD O., ASHRAF KHALIL ABDELRAHMAN S. Pattern of antibiotic abuse - a population based study in Cairo. Egyptian Journal of Chest Diseases and Tuberculosis, 62 (1), 189, 2013.

18. JUFER H., REILLY L., MOJICA E.-R.E. Antibiotics Pollution in Soil and Water: Potential Ecological and Human Health Issues. Encyclopedia of Environmental Health (Second Edition), 118, 2019.

19. DANNER M.-C., ROBERTSON A., BEHRENDS V. REISS J.. Antibiotic pollution in surface fresh waters: Occurrence and effects. Science of The Total Environment, 664, 793, 2019.

20. SALIHU DADARI H.I. Antibiotics use, knowledge and practices on antibiotic resistance among breastfeeding mothers in Kaduna state (Nigeria). Journal of Infection and Public Health, 2019.

21. SIVAGAMI K., VIGNESH V.J., SRINIVASAN R., DIVYAPRIYA G., NAMBI I.M. Antibiotic usage, residues and resistance genes from food animals to human and environment: An Indian scenario. Journal of Environmental Chemical Engineering, 2018.

22. VAN DEN BOGAARD A.E., STOBBERINGH E.E. Epidemiology of resistance to antibiotics: Links between animals and humans. International Journal of Antimicrobial Agents, 14 (4), 327, 2000.

23. TIEDJE J.M., WANG F., MANAIA C.M., VIRTA M., SHENG H., MA L., ZHANG T., TOPP E. Antibiotic Resistance Genes in the Human-Impacted Environment: A One Health Perspective. Pedosphere, 29 (3), 273, 2019.

24. SINGER R.S., FINCH R., WEGENER H.C., BYWATER R., WALTERS J., LIPSITCH M. Antibiotic resistance - the interplay between antibiotic use in animals and human beings. The Lancet Infectious Diseases, 3 (1), 47, 2003.

25. YUN S.H., JHO E.H., JEONG S., CHOI S., KAL Y., CHA S. Photodegradation of tetracycline and sulfathiazole individually and in mixtures. Food and Chemical Toxicology, 116, 108, 2018. 
26. WANG X., JIA J., WANG Y. Combination of photocatalysis with hydrodynamic cavitation for degradation of tetracycline. Chemical Engineering Journal, 315, 274, 2017.

27. MAROGA MBOULA V., HÉQUET V., GRU Y., COLIN R., ANDRĖS Y. Assessment of the efficiency of photocatalysis on tetracycline biodegradation. Journal of Hazardous Materials, 209-210, 355, 2012.

28. LYU J., HU Z., LI Z., GE M. Removal of tetracycline by $\mathrm{BiOBr}$ microspheres with oxygen vacancies: Combination of adsorption and photocatalysis. Journal of Physics and Chemistry of Solids, 129, 61, 2019.

29. WANG Y., ZHANG H., CHEN L. Ultrasound enhanced catalytic ozonation of tetracycline in a rectangular air-lift reactor. Catalysis Today, 175 (1), 283, 2011.

30. HOU L., ZHANG H., WANG L., CHEN L. Ultrasoundenhanced magnetite catalytic ozonation of tetracycline in water. Chemical Engineering Journal, 229, 577, 2013.

31. BAUTITZ I.R., NOGU EIRA R.F.P. Degradation of tetracycline by photo-Fenton process-Solar irradiation and matrix effects. Journal of Photochemistry and Photobiology A: Chemistry, 187 (1), 33, 2007.

32. FAN M., HU J., CAO R., XIONG K., WEI X. Modeling and prediction of copper removal from aqueous solutions by $\mathrm{nZVI} / \mathrm{rGO}$ magnetic nanocomposites using ANN-GA and ANN-PSO. Sci Rep, 7 (1), 18040, 2017.

33. WENQIAN R., SHI X., HU J., YU H., FAN M., CAO R., WEI X. Modeling of Malachite Green Removal from Aqueous Solutions by Nanoscale Zerovalent Zinc Using Artificial Neural Network. Applied Sciences, 8 (1), 3, 2017.

34. WENQIAN R., HU J., QI J., YU H., CAO R., WEI X. Removal of Crystal Violet by Using Reduced-GrapheneOxide-Supported Bimetallic Fe/Ni Nanoparticles ( $\mathrm{rGO} / \mathrm{Fe} /$ Ni): Application of Artificial Intelligence Modeling for the Optimization Process. Materials, 11 (5), 865, 2018.

35. FAN M., HU J., CAO R., RUAN W., WEI X. A review on experimental design for pollutants removal in water treatment with the aid of artificial intelligence. Chemosphere, 200 330, 2018.

36. FAN L., NI J., WU Y., ZHANG Y. Treatment of bromoamine acid wastewater using combined process of micro-electrolysis and biological aerobic filter. Journal of Hazardous Materials, 162 (2), 1204, 2009.

37. KALLEL M., BELAID C., MECHICHI T., KSIBI M., ELLEUCH B. Removal of organic load and phenolic compounds from olive mill wastewater by Fenton oxidation with zero-valent iron. Chemical Engineering Journal, 150 (2), 391, 2009.

38. MA L., ZHANG W.-X. Enhanced Biological Treatment of Industrial Wastewater With Bimetallic Zero-Valent Iron. Environmental Science \& Technology, 42 (15), 5384, 2008.

39. MU Y., YU H.-Q., ZHENG J.-C., ZHANG S.-J., SHENG G.-P. Reductive degradation of nitrobenzene in aqueous solution by zero-valent iron. Chemosphere, 54 (7), 789-, 2004.

40. LAI P., ZHAO H.-Z., ZENG M., NI J.-R. Study on treatment of coking wastewater by biofilm reactors combined with zero-valent iron process. Journal of Hazardous Materials, 162 (2), 1423, 2009.

41. LAI B., ZHOU Y., QIN H., WU C., PANG C., LIAN Y., $\mathrm{XU}$ J. Pretreatment of wastewater from acrylonitrilebutadiene-styrene (ABS) resin manufacturing by microelectrolysis. Chemical Engineering Journal, 179, 1, 2012.

42. BO L., ZHOU Y., PING Y. Treatment of wastewater from acrylonitrile-butadiene-styrene (ABS) resin manufacturing by $\mathrm{Fe} 0 / \mathrm{GAC}-\mathrm{ABFB}$. Chemical Engineering Journal, 200202 (none), 10, 2012.

43. ZHANG J., GUO J., WU Y., LAN Y., LI Y. Efficient activation of ozone by zero-valent copper for the degradation of aniline in aqueous solution. Journal of the Taiwan Institute of Chemical Engineers, 81, 335, 2017.

44. DAI Y., LI F., GE F., ZHU F., WU L., YANG X. Mechanism of the enhanced degradation of pentachlorophenol by ultrasound in the presence of elemental iron. Journal of Hazardous Materials, 137 (3), 1424, 2006.

45. LAI B., CHEN Z., ZHOU Y., YANG P., WANG J., CHEN $Z$. Removal of high concentration p-nitrophenol in aqueous solution by zero valent iron with ultrasonic irradiation (US-ZVI). Journal of Hazardous Materials, 250-251, 220, 2013.

46. LAI B., ZHANG Y.-H., LI R., ZHOU Y.-X., WANG J. Influence of operating temperature on the reduction of high concentration p-nitrophenol (PNP) by zero valent iron (ZVI). Chemical Engineering Journal, 249, 143, 2014.

47. REN T., YANG S., JIANG Y., SUN X., ZHANG Y. Enhancing surface corrosion of zero-valent aluminum ( $\mathrm{ZVAl}$ ) and electron transfer process for the degradation of trichloroethylene with the presence of persulfate. Chemical Engineering Journal, 348 350, 2018.

48. VINOD E.M., SINGH A.K., GANESAN R., SANGUNNI K.S. Effect of selenium addition on the GeTe phase change memory alloys. Journal of Alloys and Compounds, 537, 127, 2012.

49. CHENG H., XU W., LIU J., WANG H., HE Y., CHEN G. Pretreatment of wastewater from triazine manufacturing by coagulation, electrolysis, and internal microelectrolysis. Journal of Hazardous Materials, 146 (1), 385, 2007.

50. WANG K.-S., LIN C.-L., WEI M.-C., LIANG H.-H., LI H.-C., CHANG C.-H., FANG Y.-T., CHANG S.-H. Effects of dissolved oxygen on dye removal by zero-valent iron. Journal of Hazardous Materials, 182 (1), 886, 2010.

51. ROY G., DE DONATO P., GÖRNER T., BARRES O. Study of tropaeolin degradation by iron-proposition of a reaction mechanism. Water Research, 37 (20), 4954, 2003.

52. JOO S., FEITZ A., SEDLAK D., WAITE T. Quantification of the oxidizing capacity of nanoparticulate zero-valent iron. Environmental Science \& Technology, 39 (5), 1263, 2005.

53. ENGLEHARDT J.D., MEEROFF D.E., ECHEGOYEN L., DENG Y., RAYMO F.I.M., SHIBATA T. Oxidation of Aqueous EDTA and Associated Organics and Coprecipitation of Inorganics by Ambient Iron-Mediated Aeration. Environmental Science \& Technology, 41 (1), 270, 2007.

54. SANCHEZ I., STÜBER F., FONT J., FORTUNY A., FABREGAT A., BENGOA C. Elimination of phenol and aromatic compounds by zero valent iron and EDTA at low temperature and atmospheric pressure. Chemosphere, 68 (2), 338, 2007.

55. NORADOUN C., ENGELMANN M.D., MCLAUGHLIN M., HUTCHESON R., BREEN K., PASZCZYNSKI A., CHENG I.F. Destruction of Chlorinated Phenols by Dioxygen Activation under Aqueous Room Temperature and Pressure Conditions. Industrial \& Engineering Chemistry Research, 42 (21), 5024, 2003.

56. DONG J., ZHAO Y., ZHAO R., ZHOU R. Effects of $\mathrm{pH}$ and particle size on kinetics of nitrobenzene reduction by zero-valent iron. Journal of Environmental Sciences, 22 (11), 1741, 2010.

57. XIN Z., LIN Y.M., CHEN Z.L. 2,4,6-Trinitrotoluene reduction kinetics in aqueous solution using nanoscale 
zero-valent iron. Journal of Hazardous Materials, 165 (1), 923, 2009.

58. CAO J., LAI L., LAI B., YAO G., CHEN X., SONG L. Degradation of tetracycline by peroxymonosulfate activated with zero-valent iron: Performance, intermediates, toxicity and mechanism. Chemical Engineering Journal, 364, 45, 2019.

59. BARZEGAR G., JORFI S., ZAREZADE V., KHATEBASREH M., MEHDIPOUR F., GHANBARI F. 4-Chlorophenol degradation using ultrasound/ peroxymonosulfate/nanoscale zero valent iron: Reusability, identification of degradation intermediates and potential application for real wastewater. Chemosphere, 201, 370, 2018.

60. ZHANG M., WANG H., JIN S., FALLGREN P.H., COLBERG P.J.S. Electrochemically enhanced reduction of trichloroethene by passivated zero-valent iron. Journal of Environmental Chemical Engineering, 4 (1), 599, 2016.

61. ZHU X., NI J. The improvement of boron-doped diamond anode system in electrochemical degradation of p-nitrophenol by zero-valent iron. Electrochimica Acta, 56 (28), 10371, 2011.

62. BO L., ZHOU Y., QIN H., WU C., PANG C., YU L., XU J. Pretreatment of wastewater from acrylonitrile-butadienestyrene (ABS) resin manufacturing by microelectrolysis. Chemical Engineering Journal, 179 (1), 1, 2012.

63. LAI B.O., ZHOU Y., PING Y. Treatment of wastewater from acrylonitrile-butadiene-styrene (ABS) resin manufacturing by $\mathrm{Fe} 0 / \mathrm{GAC}-\mathrm{ABFB}$. Chemical Engineering Journal, 200-202 (1), 10, 2012.

64. HUNG H.M., HOFFMANN M.R. Kinetics and Mechanism of the Enhanced Reductive Degradation of CCl4 by Elemental Iron in the Presence of Ultrasound. Environmental Science \& Technology, 32 (19), 3011, 2000.

65. CHEN S.-S., CHENG C.-Y., LI C.-W., CHAI P.-H., CHANG Y.-M. Reduction of chromate from electroplating wastewater from $\mathrm{pH} 1$ to 2 using fluidized zero valent iron process. Journal of Hazardous Materials, 142 (1), 362, 2007.

66. HE D., SUN Y., XIN L., FENG J. Aqueous tetracycline degradation by non-thermal plasma combined with nano$\mathrm{TiO}_{2}$. Chemical Engineering Journal, 258 18, 2014.
67. ZHU X.-D., WANG Y.-J., SUN R.-J., ZHOU D.-M. Photocatalytic degradation of tetracycline in aqueous solution by nanosized $\mathrm{TiO}_{2}$. Chemosphere, 92 (8), 925, 2013.

68. SONG W., COOPER W.J., MEZYK S.P., GREAVES J., PEAKE B.M. Free Radical Destruction of ??-Blockers in Aqueous Solution. Environmental Science \& Technology, 42 (4), 1256, 2008.

69. LIU Y., HE X., FU Y., DIONYSIOU D.D. Kinetics and mechanism investigation on the destruction of oxytetracycline by UV-254 $\mathrm{nm}$ activation of persulfate. Journal of Hazardous Materials, 305, 229, 2016.

70. VARTANIAN V.H., GOOLSBY B., BRODBELT J.S. Identification of tetracycline antibiotics by electrospray ionization in a quadrupole ion trap. Journal of the American Society for Mass Spectrometry, 9 (10), 1089, 1998.

71. BALCI B., OTURAN N., CHERRIER R., OTURAN M.A. Degradation of atrazine in aqueous medium by electrocatalytically generated hydroxyl radicals. A kinetic and mechanistic study. Water Research, 43 (7), 1924, 2009.

72. DINNOCENZO J.P., KARKI S.B., JONES J.P. On isotope effects for the cytochrome P-450 oxidation of substituted $\mathrm{N}, \mathrm{N}$-dimethylanilines. Journal of the American Chemical Society, 115 (16), 7111, 1993.

73. CHEN H., LUO H., LAN Y., DONG T., HU B., WANG Y. Removal of tetracycline from aqueous solutions using polyvinylpyrrolidone (PVP-K30) modified nanoscale zero valent iron. Journal of Hazardous Materials, 192 (1), 44, 2011.

74. NIU J., LIN H.-Z., JIANG S.-G., CHEN X., WU K.-C., LIU Y.-J., WANG S., TIAN L.-X. Comparison of effect of chitin, chitosan, chitosan oligosaccharide and $\mathrm{N}$-acetyld-glucosamine on growth performance, antioxidant defenses and oxidative stress status of Penaeus monodon. Aquaculture, 372-375, 1, 2013.

75. FU Y., PENG L., ZENG Q., YANG Y., SONG H., SHAO J., LIU S., GU J. High efficient removal of tetracycline from solution by degradation and flocculation with nanoscale zerovalent iron. Chemical Engineering Journal, 270, 631, 2015. 